\title{
The Impact of the Global Financial Crisis and the Role of External and Internal Factors in Emerging Economies
}

\author{
Silvia Dal Bianco* , Chiara Amini** and Marcello Signorelli***
}

\begin{abstract}
This paper assesses the impact of external and internal factors on output loss in emerging economies during the "Great Recession". In particular, trade and capital openness are the external factors considered, while financial institutions and the quality of governance are the internal ones. The fixed effect estimates of an unbalanced panel of 122 emerging countries observed from 2008 to 2010 yields three main results. First, trade openness has played a major role in emerging markets and it has exacerbated output loss in the crisis period. Second, when significant, capital openness can help mitigate the negative impact of an external shock, but this is conditional on the level of financial development. Moreover, the development of financial markets has mattered more, in terms of direct output loss mitigation, than that of financial institutions. Finally, our analysis supports the hypothesis of possible inter-relations between financial and institutional development on the crisis's severity. For instance, a high leverage has exacerbated output loss in low-quality institution countries, while the liquidity ratio has buffered it in high-quality institution economies.
\end{abstract}

Keywords: global financial crises, trade and capital openness, financial institutions and governance, emerging economies

JEL codes: F49, G01, G20, P59 


\section{Introduction}

Drastic reductions in output growth were observed in both advanced and emerging economies between 2008 and 2010 as a consequence of the 2007-2008 global financial crisis (IMF, 2015). Different explanations have been put forward as to the origins of the crisis: global imbalances, lax financial regulation and corporate governance, over-leveraging, securitization, poor ratings agencies and inadequate monetary policy (see Kristin et al., 2012, for a complete overview). Among them, the importance of "external factors", such as global imbalances has been widely documented as one of the key crisis-triggering mechanisms in developed countries (see for example Council of Economic Advisers, 2009, and Chinn, Eichengreen and Ito, 2014).

As regards emerging markets, it has been suggested that their growth rates, during the financial crisis as well as in its aftermath, were strongly influenced not only by external factors but also by internal ones (IMF, 2014). In other words, both the classic determinants of the current account, i.e. trade and capital openness, as well as financial and institutional features, seem to have been important determinants of the crisis's severity in laggard economies. Despite the important role that the aforementioned factors may have played in making some emerging countries more vulnerable than others to such an exogenous shock, we are not aware of any study that attempts their systematic and general assessment. ${ }^{1}$ Hence, the main aim of the present work is to fill this gap in the literature. A key contribution of the present work, therefore, consists in empirical assessment of how both openness and internal institutional features affected the output response of emerging economies to the external shock of the global crisis. The internal factors considered are those related to the functioning and development of financial institutions and markets, as well as the quality of governance. In particular, the main novelty of the paper is its one-by-one assessment of the impact of individual features of the financial systems on countries' output loss due to the financial crisis. To this end, we rely on the financial indicators collected in the Cihak et al. (2012) Global Financial Development Database and, following its theoretical framework, we carefully consider the complexity of countries' financial development. More in detail, we tackle the issue of financial systems' multidimensionality by analyzing four salient 
characteristics: financial depth, access, efficiency and stability, for both financial institutions and markets. Moreover, drawing on Chinn and Ito (2006) we consider the possible inter-relations between financial and institutional development. We explore whether the impact of external and internal factors on output loss is influenced by the quality of institutions, as measured by the Kaufmann indicators of good governance.

For these purposes, we consider a panel of up to 122 emerging market economies, identified according to the IMF WEO $(2008,2015)$ lists, observed between 2008 and 2010. Our approach, which relies on a 3-year panel, is motivated by the fact that the timing of the crisis was different across countries. As noted by Claessens et al. (2010), if one looks only at growth in 2008, the picture may not be very realistic because some countries that appear to have been relatively unscathed in 2008 were badly hit in 2009 , and to a lesser extent in 2010. In particular, various studies (see Didier et al., 2011, for a review) have documented that emerging countries were hit hardest in 2009 , the central year in our three-year panel.

The main results of our analysis can be summarized as follows. First, trade openness has played a major role in emerging markets, and it has exacerbated output loss in the crisis period. Second, when significant, capital openness has mitigated crisis output loss. However, capital openness statistical significance is related to the internal characteristics of financial systems. Moreover, it has been found that the development of financial markets has mattered more, in terms of direct output loss mitigation, than that of financial institutions. Finally, our analysis has highlighted some inter-relations between financial and institutional development. In particular, it has been shown that the stability of financial institutions is relevant only when institutional quality has been considered. Overall the results of our analysis contribute to extending the existing literature and are in line with those of Fratzscher (2011) and Lane (2013) in so far as they show that crisis responses have been highly heterogeneous across countries.

The rest of the paper is organized as follows. Section 2 provides an overview of the data and the methodology employed. Section 3 contains some descriptive evidence and the discussion of the main econometric results. We conclude with some final remarks and policy implications. 


\section{Empirical Specification, Econometric Technique and Data}

As explained in the Introduction, the main objective of this paper is to conduct a systematic assessment of the role played by both external and internal factors in emerging economies' output loss due to the global financial crisis, with particular regard to the characteristics of financial systems and the quality of governance.

As for the external factors, we consider the traditional determinants of the current account, which are trade and capital openness. Instead, as regards the internal features, we explicitly consider the development and functioning of financial institutions and markets, as well as the quality of governance.

The unified empirical framework adopted here makes it possible to take both external and internal factors into consideration. It is formally written as:

$$
\text { Crisis }_{i t}=\beta_{0}+\beta_{1} T O_{i t}+\beta_{2} K O_{i t}+\beta_{3} F D_{i t}+\varepsilon_{i t}
$$

where $i$ and $t$ respectively indicate countries and years, Crisis represents the output loss due to the global financial crisis, $T O$ and $K O$ measure trade and capital openness, $F D$ stands for any characteristic of financial development considered here, and $\varepsilon_{i t}$ is the idiosyncratic error term.

Drawing on Berkmen et al. (2012), Crisis was computed as the difference between actual GDP growth outturns in 2008, 2009 and 2010 and those forecasted before the crisis acquired its global nature. ${ }^{2}$ In particular, we calculated this indicator for 2008 as the difference between the GDP growth rate prediction as published by the IMF (WEO) in April 2008 and the actual data reported in the latest issue of the same publication, which dates to April 2015. Similarly, in order to compute the crisis indicator in 2009 (2010), we took the difference between the growth prediction made for 2009 (2010) by the April 2008 WEO and the actual 2009 (2010) data reported in WEO April 2015. ${ }^{3}$ In essence, our crisis indicator represents the "growth surprises" that can be ascribed to the global financial crisis. Hence, by its construction, the indicator rules out a number of serious endogeneity issues (e.g. simultaneity) that might undermine the consistency of any econometric result. 
Moreover, because it was calculated for three years (2008-2010), it makes it possible to provide a realistic picture of the costs, in output terms, associated with the Great Recession.

Turning to the other variables, TO was taken as the sum of exports and imports ratios to GDP. The data come from World Bank Development Indicators. $K O$ is the Chinn Ito Index, as in its latest release, i.e. January 2015. Chinn and Ito (2006) introduced an index to measure the degree of capital openness, called KAOPEN. This index is the first standardized principal component of the four binary variables measured in the IMF Annual Report on Exchange Arrangements and Exchange Restrictions (AREAER). These variables are indicator variables for (i) the existence of multiple exchange rates, (ii) restrictions on current account, (iii) restrictions on capital account transactions and (iv) a variable indicating the requirement of the surrender of export proceeds. The Chinn-Ito index is normalized between zero and one. The more open the country, the higher the value of the Chinn-Ito index.

The variable FD captures some salient features of financial intermediaries and markets that, in the spirit of Beck et al. (2000 and 2009) and Cihak et al. (2012), describe the functioning of the financial side of an economy. In particular, following the $4 \times 2$ matrix of Cihak et al. (2012), we considered the depth, the accessibility, the efficiency, and the stability of both financial intermediaries and markets. Overall, we analysed the impact of 26 variables selected on the basis of data availability. See Table A1 in the appendix for full details on the financial variables employed.

In order to assess how the quality of governance affected the responsiveness to the global crisis, we investigated whether the impact of the variables of interest depended on countries' institutional set-ups. A growing number of studies have recently provided supportive evidence for the likely non-linearity between both the external and the internal factors considered here and political institutions. Hence, given the likely interrelations among trade, capital openness, financial development and institutions, the impact of our explanatory variables on crisis output loss can be expected to change depending on the country's institutional environment. To measure institutional quality we employed the Kaufmann indicators of good governance. More specifically, we aggregated three of the available indictors, namely Rule of Law, Control of Corruption and Bureaucratic quality, into a composite 
index calculated using the Cronbach Coefficient Alpha ${ }^{4}$. To understand how trade, capital openness and the functioning of the financial system affected the extent of the crisis in different institutional environments, we divided our sample into two groups of countries, namely countries with good institutional quality and countries with very low institutional quality. This division was made on the 25th percentile of the aggregate institutional index for the sample considered. Hence countries for which the institutional indicator assumed a value above the $25^{\text {th }}$ percentile were classified as good quality institutions, and as ones of very low quality otherwise. ${ }^{5}$ For conciseness, we only report the results based on the aggregate index. However, we repeated the same exercise for the six institutional indicators provided by the Kaufmann dataset (government effectiveness, political stability, rule of law, corruption control, voice and accountability and regulatory quality. See Table A1 for full details on the institutional variables employed. ${ }^{6}$

Our econometric analysis relied on a fixed effects estimator on an unbalanced panel of 122 emerging countries, observed between 2008 and 2010 and identified according to the lists reported in the IMF WEO $(2008,2015)$. In order to avoid endogeneity issues, all the right hand side variables of Equation (1) were taken as the average of the previous three years, while, given the high persistency of institutions, such indicators are contemporaneous (see Berkmen et al., 2012; and Chinn, Ito and Eichengreen, 2014 for similar choices). Moreover, the main advantages of a panel with a fixed effect estimator is that the omitted variable bias is largely avoided by controlling for country level heterogeneity. This is particularly important in this context, because the sampled countries exhibit high levels of time invariant heterogeneity (e.g., resource abundance, geographical position and morphology). ${ }^{7}$

\section{Results}

\subsection{Descriptive Evidence}

Tables 1-4 report countries listed by institutional quality and summary statistics. We have data on 122 countries. There are up to 31 countries in the low institutions group and up to 133 in the high institutions one. The number of 
observations available varies across the variable considered. For instance we have up to 309 observations for trade, capital openness and measures of financial stability, but as few as 149 observations for indicators financial market depth.

To gain better understanding of the relationship between institutions and characteristics of financial systems, we first investigate whether financial systems are systematically different between the two groups of interest (very low vs. good quality institutions). The depth of financial institutions and markets is generally greater in good-quality institutions countries (especially if measured by the level of government effectiveness). For instance, the ratio of bank private credit to GDP is $13 \%$ in the low-quality institutions group and $34 \%$ in the high-quality one. This means that financial institutions provide higher credit services in good-quality institutions countries. Unsurprisingly, there is greater access to financial institutions in good-quality institutions countries, where the number of bank accounts per 1000 adults is 593, against 90 in the very low-quality institutions group.

The indicators of the efficiency of financial institutions are also systematically different between the two groups. Generally, the data indicate that financial institutions are more efficient in countries with good-quality political institutions. For instance, overhead costs to total assets and the cost to income ratios are higher in very low-quality institutions countries. But there are exceptions. Returns on assets (ROA) and on equity (ROE) are higher in the low-quality institutions group. Credit to

government and state-owned enterprises (SOEs) to GDP is higher in the good-quality institutions group. This is to be expected, given the prominence that the SOEs of emerging markets have acquired in the past few years. Indeed, UNCTAD (2014) documents that SOEs account for more than $11 \%$ of global FDI flows, and that $60 \%$ of the latter are from emerging markets.

\subsection{Econometric Results}

Our empirical analysis was based on two main exercises. First, we estimated Equation (1) for the entire sample of emerging economies. Hence, we assessed the importance of trade and capital openness as well as financial system's characteristics for output loss due to the financial crisis. Tables 5 to 8 report the results. Second, we estimated (1) in two distinct groups of countries: those with high and those with low 
institutional quality. We were thus able to identify whether the impact of the internal and external factors on the crisis's severity was dependent on countries' institutional set-ups. Tables 9-11 collect these estimates.

Overall, our results can be summarized as follows. First, trade openness has played a major role in emerging markets, and it has exacerbated output loss in the period of crisis. Second, when significant, capital openness has mitigated crisis output loss. Third, capital openness statistical significance is related to the internal characteristics of financial systems, and to the depth of institutions and markets in particular. Fourth, the development of financial markets has mattered more, in terms of direct output loss mitigation, than that of financial institutions. ${ }^{8}$ Fifth, the stability of financial institutions turns out to be relevant only when institutional quality has been considered, while the effects of financial markets' depth seem to be unrelated with political institutions. Finally, the accessibility of financial institutions has had no effect across specifications.

More in detail, as regards trade openness, the results reported in Tables 5-8 show that an increase of one percentage point in the aforementioned variable has led to an average loss of 2 percentage points of output growth. This finding holds across specifications, and the magnitude of the effect ranges from 0.8 to 3.3 percentage points. Qualitatively, our results confirm the detrimental effect of trade openness already found by a large part of the established literature. ${ }^{9}$ For example, Claessens et al. (2010) note that, in emerging economies, output contraction due to the 2007-2008 financial crisis only started once the collapse in global demand had led to a contraction of global trade. Hence, according to their analysis, especially small open economies and countries heavily reliant on exports suffered from the decline in international trade and the difficulty of financing trade. The same conclusion that trade openness made countries more vulnerable to the crisis has been reached by the cross-sectional analysis of the first year of the crisis conducted by Berkmen et al. (2012). Moreover, on the basis of dynamic panel models, DablaNorris et al. (2015) have highlighted the importance of trade orientation and production structure for sensitivity to foreign shocks. In particular, this work shows that emerging countries have high elasticity of growth to trading partners' growth, and that for commodity-exporting developing economies in Sub-Saharan Africa and 
the Middle East the main channels of transmission of foreign shocks are those of emerging market leaders like China. It should be also mentioned that a part of the literature - not focusing on the "Great Recession" period - has found that trade openness makes countries less vulnerable to severe sudden stops (e.g. Cavallo and Frankel, 2008).

Turning to capital openness, our results show that "financial globalisation" did not have a significant impact on output loss in emerging markets (see Tables 511). This general finding is in line with those of Chinn, Ito and Eichengreen (2014), who show that capital openness did not play a major role in determining the current account behaviour in emerging countries for the period 2006-2008. In addition, Broner et al. (2013) show limited foreign capital retrenchment in emerging markets' economies during crises. $^{10}$ Nonetheless, on closer inspection of Table 5, it is interesting to note that capital openness has a significant mitigating effect when we control for deposit money bank assets to overall deposit assets (Column 3) and central bank assets (Column 5). In particular, an increase of one percentage point in capital openness is associated with a 0.45 percentage points lower output loss. This is consistent with the descriptive evidence provided by Lane (2013), which shows that financial openness amplified the crisis in some countries, whereas it provided a buffer for others. In particular, our findings seem to suggest that capital openness mitigated the impact of the crisis in countries with relatively better political institutions (see Table 9, Column 3 and 4), and also if we control for the size of central bank assets to GDP. ${ }^{11}$

The analysis of internal factors, namely financial systems' characteristics and the quality of governance, shows that the efficiency of financial institutions and the depth of financial markets have played a role in the overall sample (see Tables 7 and 8), while institutions' depth and stability turn out to be significant only when the quality of governance is considered (see Tables 9 and 10). As regards Financial Institutions' Efficiency (i.e. Table 10), our results show that higher returns on financial institutions' assets (Column 5 ) and higher credit to government (Column 8) made countries more vulnerable to the crisis while a higher lending-deposit spread (Column 2) mildly mitigated crisis output loss. These findings seem to support - from a very specific perspective - the much more general views expressed by De Gregorio 
and Guidotti (1995) and Méon and Weill (2010), who envisage a negative relationship between growth and the functioning of the financial system. ${ }^{12}$

Turning to Financial Markets, Table 8 shows that the depth of markets, as measured through International Debt issues (Column 3), as well as Equity and Debt liabilities (Columns 4 and 6), significantly cushioned the effect of the crisis on output. Hence, fund-raising by financial markets from foreign investors as well as from short or long term investors turns out to be very important in the context of emerging markets. This result can also partly support the "financial catch-up" hypothesis of Goyal et al. (2011), as debt is often associated with final stages of the financial growth cycle, as illustrated by Berger and Udell (1998).

Turning to the relationship between financial system functioning and governance, Table 9 (Columns 1, 2 and 5) shows that Financial Institutions' depth was detrimental in countries characterized by low institutional quality. Moreover, as far as stability is concerned, Table 10 supports the findings of Berkmen et al. (2012), since it shows that a high leverage exacerbated output loss in low-quality institution countries (Table 10, column 1), while the liquidity ratio buffered the output loss, but only in high-quality institution economies (Table 10, column 2). As for the accessibility of financial systems, as measured by bank accounts or bank branches per inhabitant, Table 6 (Columns 1 and 2 ) shows that this feature had no effect on output loss, even when institutional quality is taken into account. In this regard, it is important to note that Cihak et al. (2012) document that the global financial crisis generated less financial stability and less access. Hence, it seems that restricted access to financial services did not impact on countries' vulnerability, while liquidity availability did so, especially in low-quality institution economies.

Overall, the results of our analysis are in line with those of Fratzscher (2011), which highlight that crisis responses were highly heterogeneous across countries, and that a large part of this heterogeneity can be explained by differences in the quality of domestic institutions.

\section{Conclusions and policy implications}

This study has empirically assessed how both (trade and capital) openness and several internal institutional features affected the 2008-2010 output response 
of emerging economies to the external shock of the global financial crisis and the consequent "Great Recession". The internal factors considered have been those related to the quality of governance and to the functioning and development of financial institutions and markets. The main novelty of our analysis is its one-by-one assessment of the impact of individual features of financial systems on countries' output loss.

Our results show that trade openness has played a major role in emerging economies by exacerbating output losses due to the global financial crisis; this finding is significant in all specifications, and the magnitude of the effect is remarkable. Capital openness statistical significance is related to some internal characteristics of financial systems (the depth of financial institutions and markets in particular) and, when significant, it contributed to mitigating crisis output loss, especially in countries with high quality institutions. Moreover, we have found that the development of financial markets has mattered more, in terms of output loss mitigation, than that of financial institutions; however, a distinction of the sample countries between market-based vs. bank-based financial systems produced not significant results. Finally, we have found supportive evidence on the inter-relations between financial and institutional development. In particular, the stability of financial institutions appears to be relevant only when institutional quality is considered. In addition, we have obtained a number of more specific results, of which here we highlight only the following: (i) higher returns on financial institutions' assets and a higher ratio between credit by domestic money banks to the government and state-owned enterprises to GDP (two of the variables measuring the efficiency of financial institutions) made countries more vulnerable to the impact of the global crisis while a higher lending-deposit spread mildly mitigated crisis output loss; (ii) the depth of markets, as measured through International Debt issues as well as Equity and Debt liabilities, significantly cushioned the effect of the crisis on output; (iii) the depth of Financial Institutions was detrimental in countries characterized by low institutional quality; (iv) a high leverage has exacerbated output loss in low-quality institution countries; ( $v$ ) a higher liquidity ratio buffered the output loss but only in high-quality institution economies. 
As for the policy implications, a first obvious but important consideration concerns the huge consequences that a financial crisis originating in a big country, such as the US, may have in today's globalised context (dominated by a high and growing trade openness and financial interdependences): a well-designed "regulatory and governance system" is crucial for preventing the occurrence of global financial crises. ${ }^{13}$ Before turning to more specific policy implications, it should be borne in mind that the policy implications derived from any analysis conducted in "normal times" are necessarily different from those that can be deduced from "crisis times" (i.e. when the impact of an external negative shock is investigated). Given the period of time analyzed here, the policy implications of the present analysis center on the relative importance of external and internal factors in crisis times. ${ }^{14}$ Over the past decades, a growing body of theoretical and empirical literature has shown the prevailing beneficial impact of greater openness on economic growth and development. However, more open (especially small) economies suffer more from the worsening of the (growth rate of) international trade that accompanies a global financial crisis, and they need to have room for more active counter-cyclical macroeconomic policies. Our results suggest that capital openness can help mitigate the negative impact of an external shock, but this is conditional on institutional quality. Therefore structural policies improving the quality of governance are needed to increase resilience to external negative shocks. The investigation of the various financial institutions and markets features does not allow the drawing of general policy implications, for example in favor of more market-based or more bank-based financial systems. As regards more specific policy implications, we mention only that policy makers (i) should be aware that higher bank credit to state-owned enterprises may be associated with greater output loss, (ii) should promote improvement in the quality of institutions (especially in the countries where they are of low quality). In fact, according to our results, high quality governance makes it possible to avoid the negative effect linked to higher depth and leverage of financial institutions, while it permits the positive effect related to a higher liquidity ratio.

Our results contribute to shedding more light on the determinants of the severity of the 2008 global financial crisis and the consequent "Great Recession" in emerging economies. Our results could also stimulate further theoretical and 
empirical research on the topic of heterogeneous responses to external big shocks. On this latter point, it would be important to evaluate whether trade as well as capital compositions matter for emerging economies in the case of big external shocks like the last global financial crisis. Moreover, in order to derive clearer policy implications, it would be crucial to measure the medium-run impact of external and internal factors in emerging economies in terms of "cumulative output losses" (i.e. including some additional years in the aftermath of the 2008 global financial crisis).

\section{References}

Beck T., Demirgüç-Kunt A. and Levine R. (2000), "A New Database on Financial Development and Structure," World Bank Economic Review 14, 597-605.

Beck T., Demirgüç-Kunt A. and Levine R. (2009), Financial Institutions and Marketsacross Countries and over Time. Data and Analysis, Policy Research Working Paper, n. 4943, The World Bank.

Beck T. and Levine R. (2002), Industry growth and capital allocation: : does having a market- or bank-based system matter? Journal of Financial Economics, 64, 2, 147-180.

Berger A. N. and Udell G. F. (1998), The economics of small business: the roles of private equity and debt markets in the financial growth cycle, Journal of Banking \& Finance, 22, 6-8, 613-673.

Berkmen S.P., GelosG., Rennhack R. and Walsh J.P. (2012), The global financial crisis: Explaining cross-country differences in the output impact, Journal of International Money and Finance, 31, 42-59.

Bonnala M. and Yayab M.E. (2015), Political Institutions, Trade Openness, and Economic Growth: New Evidence, Emerging Markets Finance and Trade, 51, 6, 1276-1291.

Broner F., Didier T., Erce A. and Schmukler S.L. (2013), "Gross Capital Flows: Dynamics and Crises", Journal of Monetary Economics, 60, 1, 113-33.

Cavallo E. and Frankel J.A. (2008), "Does openness to trade make countries more vulnerable to sudden stops, or less? Using gravity to establish causality", Journal of International Money and Finance, 27, 8, 1430-1452. 
Chakraborty S. and Ray T. (2006), Bank-based versus market-based financial systems: A growth-theoretic analysis, Journal of Monetary Economics, 53, 2, 329-350.

Chang R., Kaltani L. and Loayza N. (2005), Openness Can be Good for Growth: The Role of Policy Complementarities, NBER Working Paper, 11787.

Chinn, M.D. and Ito H. (2006), "What Matters for Financial Development? Capital Controls, Institutions, and Interactions",Journal of Development Economics, 81, 1, 163-192.

Chinn, M.D. and Ito H. (2008), "A New Measure of Financial Openness", Journal of Comparative Policy Analysis, 10, 3, 309-322.

Chinn, M. D., Eichengreen, B. and Ito H. (2014), "A forensic analysis of global imbalances", Oxford Economic Papers, 66, 2, 465-490.

Čhhák, M., Demirgüç-Kunt, A., Feyen, E. and Levine, R. (2012),“Benchmarking Financial Systems around the World",Policy Research Working Paper, 6175, The World Bank.

Claessens S., Dell'Ariccia G., Igan D., and Laeven L. (2010), “Cross-Country Experiences and Policy Implications from the Global Financial Crisis", Economic Policy, 62, 267-293.

Council of Economic Advisers (2009), Economic Report of the President, Washington, D.C., Executive Office of the President.

Dabla-Norris E., Espinoza R. and Jahan S. (2015), Spillovers to Low-Income Countries: Importance of Systemic Emerging Markets, Applied Economics, 47, 53, 57075725.

De Gregorio, J. and Guidotti, P. (1995), "Financial Development and Economic Growth," World Development, 23, 3, 433-448.

Didier T., Hevia C. and Schmukler S. (2011), Emerging market resilience, VOX CEPR's Policy Portal, http://www.voxeu.org/article/resilience-emerging-marketsduring-global-crisis [accessed 14-9-2015].

FratzscherM.(2012), "Capital flows, push versus pull factors and the global financial crisis",Journal of International Economics, 88, 2, 341-356.

Gambacorta L., Yang J. and Tsatsaronis K. (2014), Financial structure and growth, BIS Quarterly Review, March, 21-37. 
Goyal R., Marsh C., Raman N., Wang S. and Ahmed S. (2011), "Financial Deepening and International Monetary Stability", IMF Staff Discussion Note, SDN/11/16.

International Monetary Fund (2008),World Economic Outlook, Washington DC, April. International Monetary Fund (2015),World Economic Outlook, Uneven Growth: Short- and Long-Term Factors, Washington DC, April.

International Monetary Fund (2014),World Economic Outlook, Recovery Strengthens, Remains Uneven, Washington DC, April.

KristinF.J., Engel C. and Frankel J. (2012), "Introduction to the Special Issue on the Global Financial Crisis", Journal of International Economics, 88, 2, 215-218.

Kutan A.M. (2015), Financial and Real Sector Challenges in Emerging Economies, Emerging Markets Finance and Trade, 51, Supplement 1, S1-S2.

Lane P.L. (2013), "Financial Globalisation and the Crisis", Open Economies Review, $24,3,555-580$.

Levine R. (2002), Bank-Based or Market-Based Financial Systems: Which Is Better?, Journal of Financial Intermediation, 11, 4, 398-428.

Maa Y. (2015), Financial Openness, Financial Frictions, and Macroeconomic Fluctuations in Emerging Market Economies, Emerging Markets Finance and Trade, 52, 1, 169-187.

Marelli E. and Signorelli M. (2015), "Convergence, crisis and unemployment in Europe:the need for innovative policies", Croatian Economic Survey, 17, 2, 5-56.

Méon P.G. and Weill L. (2010), "Does financial intermediation matter for macroeconomic performance?", Economic Modelling, 27, 296-303.

OECD (2008), Handbook on Constructing Composite Indicators. Methodology and User Guide, Paris. 
DESCRIPTIVE STATISTICS \& COUNTRY LIST

Table 1- List of Countries*

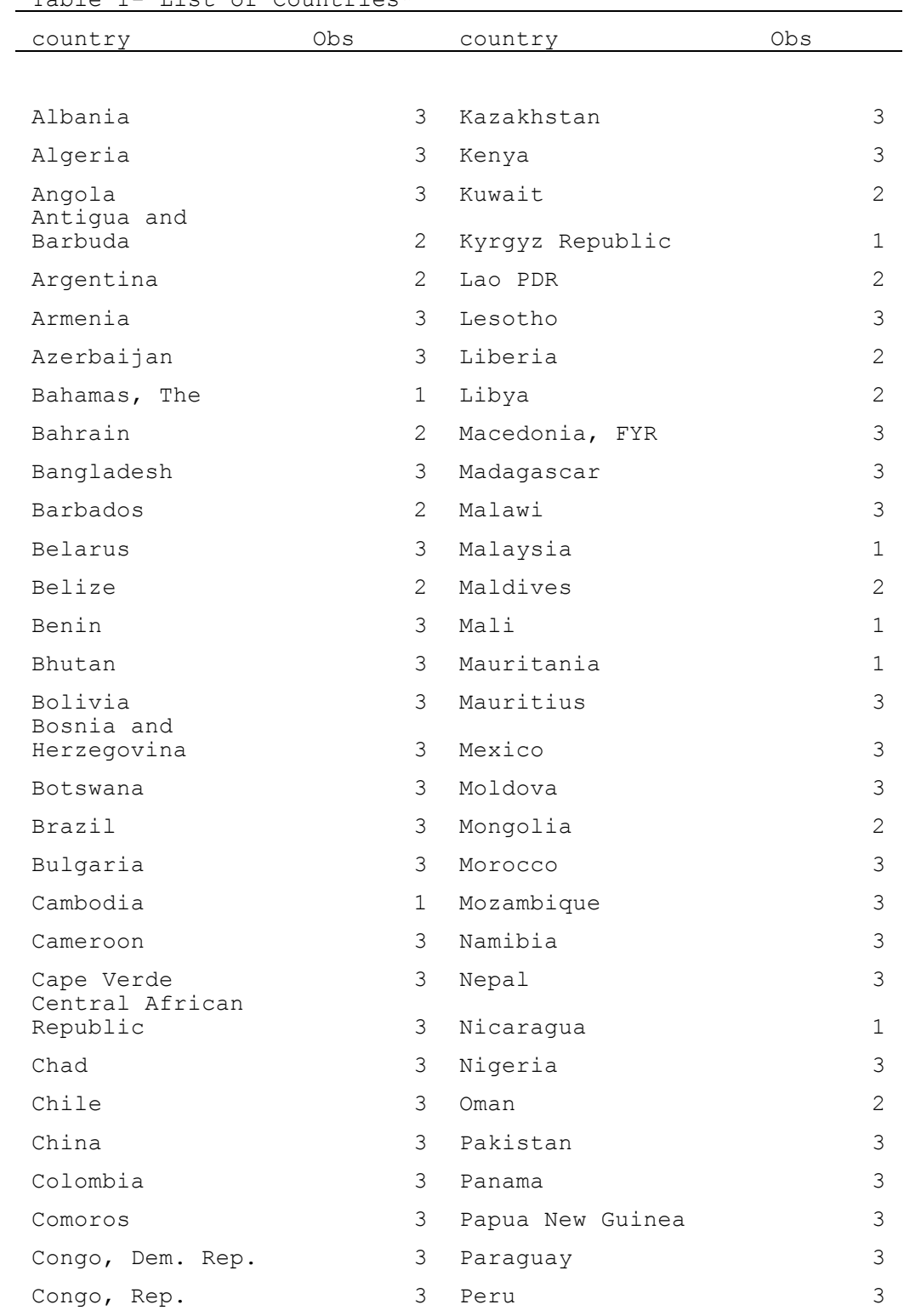




\begin{tabular}{|c|c|c|c|}
\hline Costa Rica & 3 & Philippines & 3 \\
\hline Cote d'Ivoire & 3 & Poland & 3 \\
\hline Croatia & 3 & Qatar & 1 \\
\hline Djibouti & 1 & Romania & 3 \\
\hline $\begin{array}{l}\text { Dominica } \\
\text { Dominican }\end{array}$ & 2 & Russia & 3 \\
\hline Republic & 3 & Samoa & 2 \\
\hline Ecuador & 3 & Saudi Arabia & 3 \\
\hline Egypt, Arab Rep. & 3 & Senegal & 3 \\
\hline El Salvador & 3 & Seychelles & 3 \\
\hline Equatorial Guinea & 3 & Sierra Leone & 3 \\
\hline Eritrea & 1 & South Africa & 2 \\
\hline Estonia & 1 & Sri Lanka & 3 \\
\hline Ethiopia & 2 & $\begin{array}{l}\text { St. Lucia } \\
\text { Vincent and the }\end{array}$ & 2 \\
\hline Fiji & 3 & Grenadines & 2 \\
\hline Gabon & 3 & Sudan & 1 \\
\hline Gambia, The & 3 & $\begin{array}{l}\text { Swaziland } \\
\text { Syrian Arab }\end{array}$ & 3 \\
\hline Georgia & 3 & Republic & 3 \\
\hline Ghana & 3 & Tajikistan & 2 \\
\hline Grenada & 2 & Thailand & 2 \\
\hline Guatemala & 3 & Togo & 1 \\
\hline Guinea-Bissau & 2 & Tonga & 2 \\
\hline Guyana & 2 & Trinidad and Tobago & 2 \\
\hline Haiti & 2 & Tunisia & 3 \\
\hline Honduras & 3 & Turkey & 3 \\
\hline Hungary & 2 & Uganda & 3 \\
\hline India & 3 & $\begin{array}{l}\text { Ukraine } \\
\text { United Arab }\end{array}$ & 3 \\
\hline $\begin{array}{l}\text { Indonesia } \\
\text { Iran, Islamic }\end{array}$ & 3 & Emirates & 1 \\
\hline Rep. & 1 & Uruguay & 3 \\
\hline \multirow[t]{3}{*}{ Jordan } & 3 & Venezuela & 3 \\
\hline & & Vietnam & 3 \\
\hline & & Zambia & 3 \\
\hline
\end{tabular}

- Observations based on the regression in Table 4 column 8 . 
Table 2 - Summary Statistics

\begin{tabular}{|c|c|c|c|c|c|c|}
\hline Variable & Obs & & Mean & Std. Dev. & Min & $\operatorname{Max}$ \\
\hline mGFDDDI 01 & & 296 & 30.94615 & 22.74769 & 1.696558 & 104.8281 \\
\hline mGFDDDI 02 & & 298 & 38.9858 & 25.93611 & 2.312291 & 115.7957 \\
\hline mGFDDDI 04 & & 267 & 86.50685 & 15.00538 & 5.715824 & 99.99958 \\
\hline mGFDDDI 05 & & 298 & 44.11379 & 26.61273 & 6.041292 & 149.0429 \\
\hline mGFDDDI 06 & & 262 & 5.822995 & 14.87474 & 0.0002653 & 169.7348 \\
\hline mGFDDDI 08 & & 286 & 36.18711 & 23.46013 & 4.150724 & 135.3975 \\
\hline mGFDDDI 12 & & 296 & 32.40544 & 24.82649 & 1.696558 & 146.2422 \\
\hline mGFDDDM0 1 & & 161 & 46.79247 & 46.25361 & 0.5336372 & 243.5069 \\
\hline mGFDDDM0 2 & & 158 & 21.37397 & 42.37168 & 0.0170923 & 289.9579 \\
\hline mGFDDDM0 7 & & 141 & 10.35107 & 9.791357 & 0.0392266 & 48.636 \\
\hline mGFDDDM0 8 & & 140 & 5.2954 & 7.910649 & 0.0088752 & 47.97027 \\
\hline mGFDDDM0 9 & & 147 & 4.360226 & 11.22492 & 0.0036124 & 67.97853 \\
\hline mGFDDDM1 0 & & 149 & 8.507427 & 15.72192 & 0.0000674 & 111.2168 \\
\hline mGFDDAI 01 & & 129 & 515.0772 & 593.3292 & 2.813517 & 3106.095 \\
\hline mGFDDAI 02 & & 193 & 11.44559 & 13.59313 & 0.4074766 & 91.0957 \\
\hline mGFDDEI 01 & & 265 & 4.297437 & 2.000359 & -3.360049 & 12.06948 \\
\hline mGFDDEI 02 & & 243 & 8.602765 & 6.122725 & 0.4277779 & 39.1042 \\
\hline mGFDDEI03 & & 257 & 37.38115 & 14.72348 & 2.130245 & 166.0805 \\
\hline mGFDDEI 04 & & 254 & 4.028482 & 2.268533 & 0.0634683 & 13.19367 \\
\hline mGFDDEI 05 & & 290 & 1.680146 & 1.341008 & -13.55811 & 5.403605 \\
\hline mGFDDEI 06 & & 290 & 16.16535 & 18.96892 & -120.5436 & 136.3415 \\
\hline mGFDDEI 07 & & 287 & 55.44072 & 13.60018 & 14.60983 & 109.4866 \\
\hline mGFDDEI 08 & & 309 & 8.693558 & 9.077525 & 0.126241 & 61.35155 \\
\hline mGFDDSI 01 & & 289 & 18.11785 & 9.201635 & 4.047398 & 51.57125 \\
\hline mGFDDSI 04 & & 300 & 95.9543 & 67.41942 & 22.41579 & 622.6824 \\
\hline mGFDDSI 06 & & 284 & 37.56989 & 16.64266 & 8.227704 & 104.2282 \\
\hline mtrade 2 & & 309 & 0.9085567 & 0.3796646 & 0.2589546 & 2.421892 \\
\hline mkaopen & & 309 & 0.1557091 & 1.493626 & -1.888895 & 2.389668 \\
\hline gov & & 226 & -0.2913589 & 0.6039522 & -1.573231 & 1.225874 \\
\hline
\end{tabular}




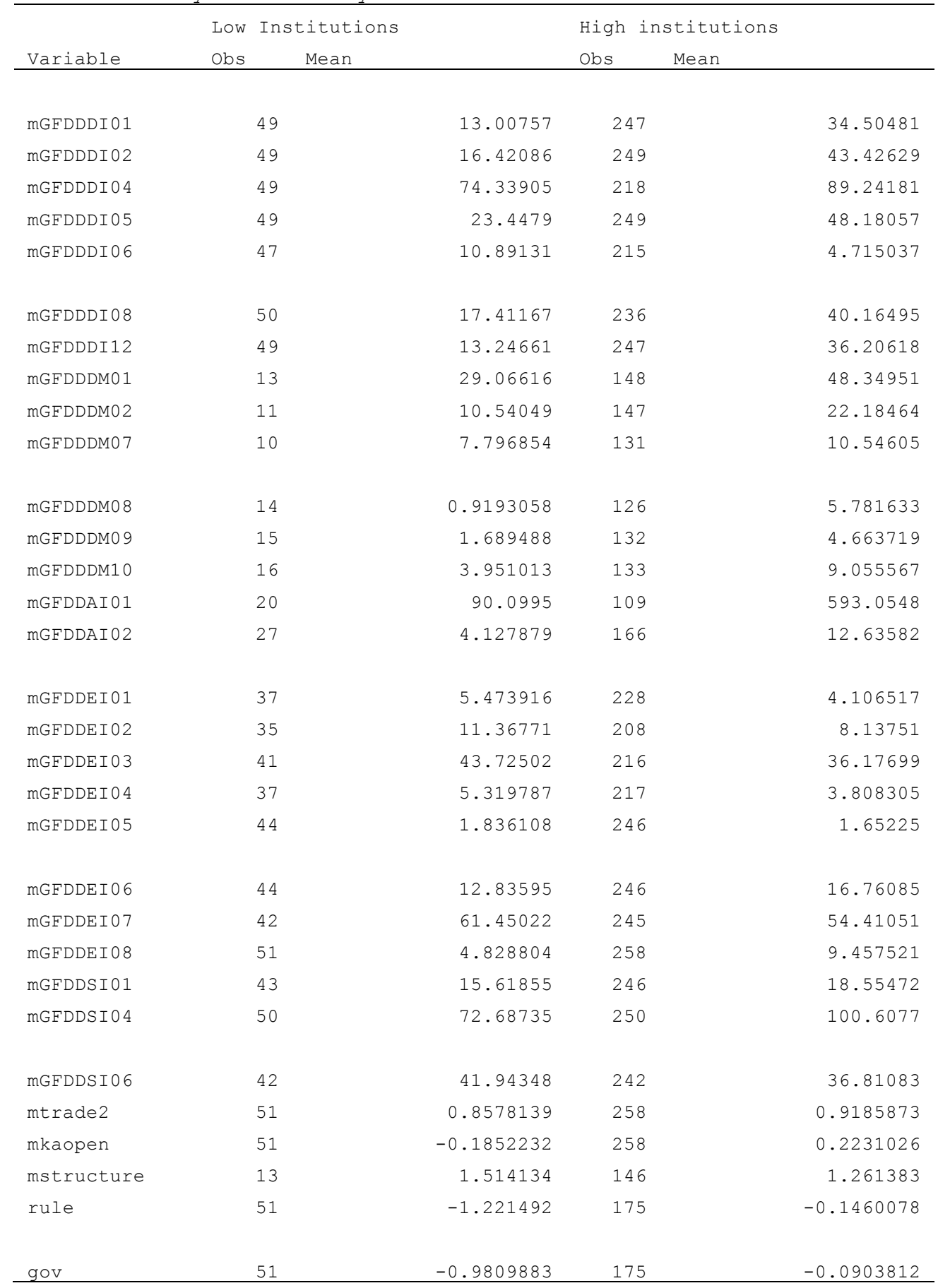


Table 4

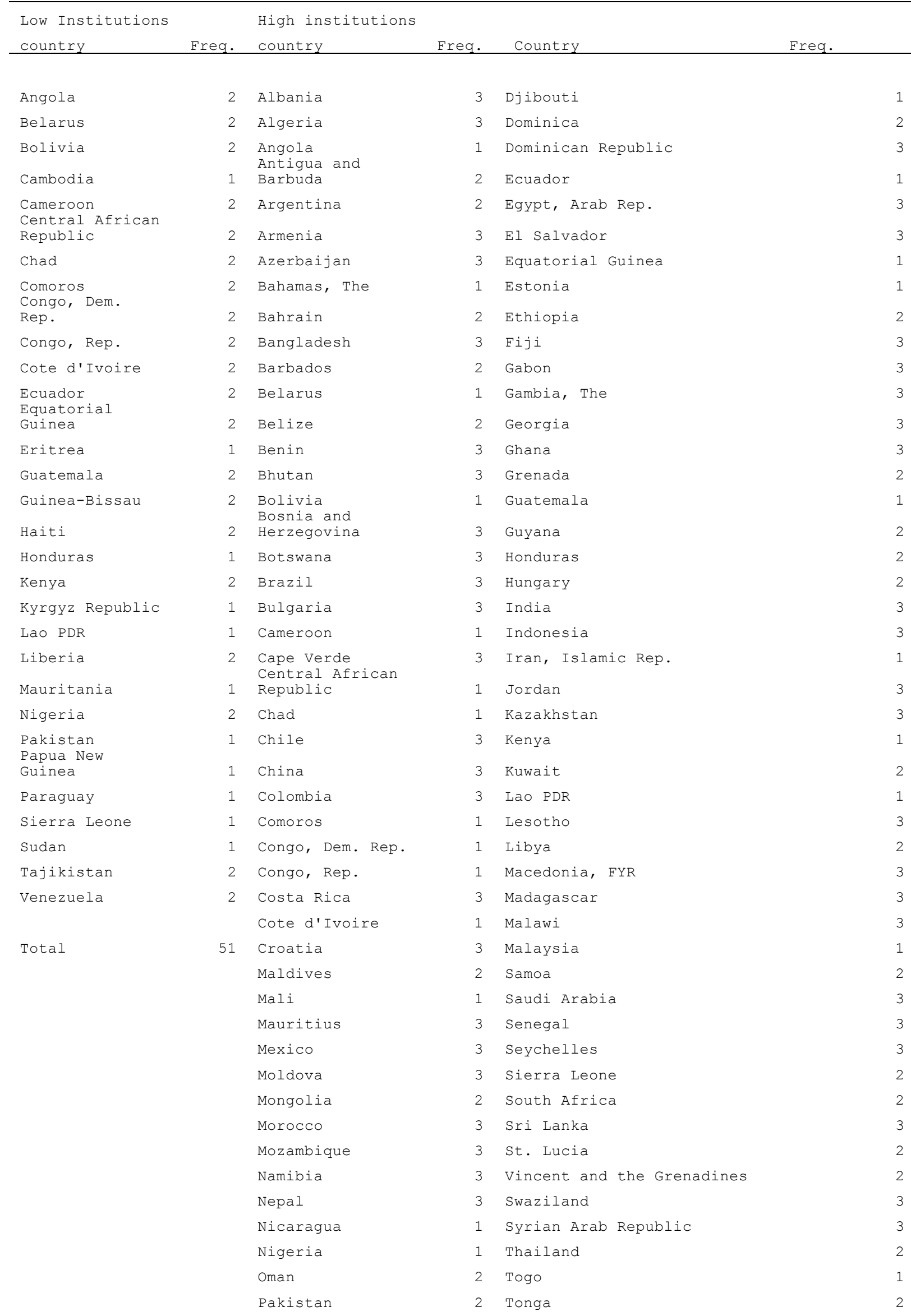




\begin{tabular}{|c|c|c|c|}
\hline Panama & 3 & Trinidad and Tobago & 2 \\
\hline Papua New Guinea & 2 & Tunisia & 3 \\
\hline Paraguay & 2 & Turkey & 3 \\
\hline Peru & 3 & Uganda & 3 \\
\hline Philippines & 3 & Ukraine & 3 \\
\hline Poland & 3 & United Arab Emirates & 1 \\
\hline Qatar & 1 & Uruguay & 3 \\
\hline Romania & 3 & Venezuela & 1 \\
\hline \multirow[t]{2}{*}{ Russia } & 3 & Vietnam & 3 \\
\hline & & Zambia & 3 \\
\hline
\end{tabular}

TABLES - all countries

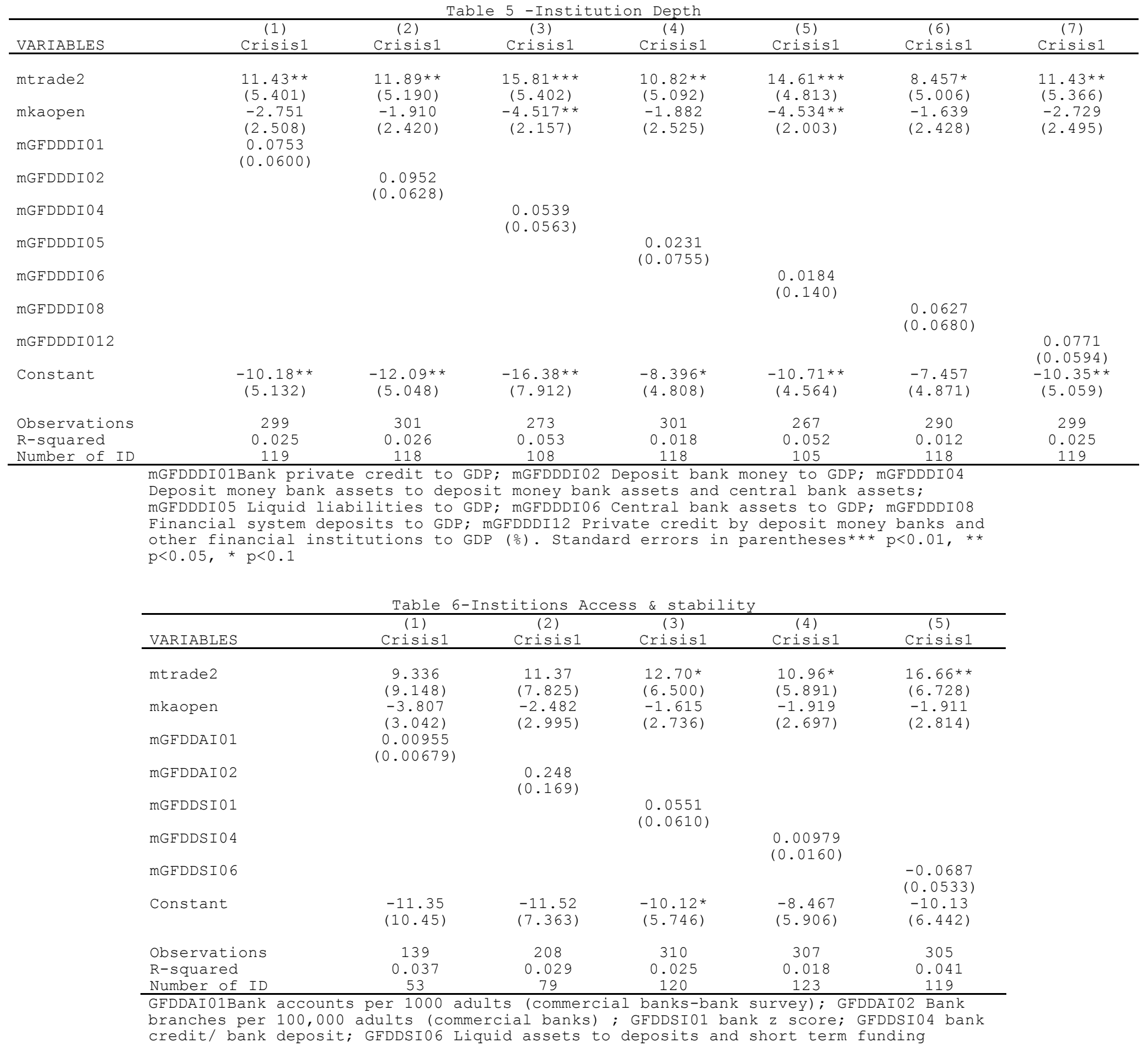


(응 Standard errors in parentheses $* * p<0.01, * \star p<0.05, * p<0.1$

Table 7-Institions Efficiency

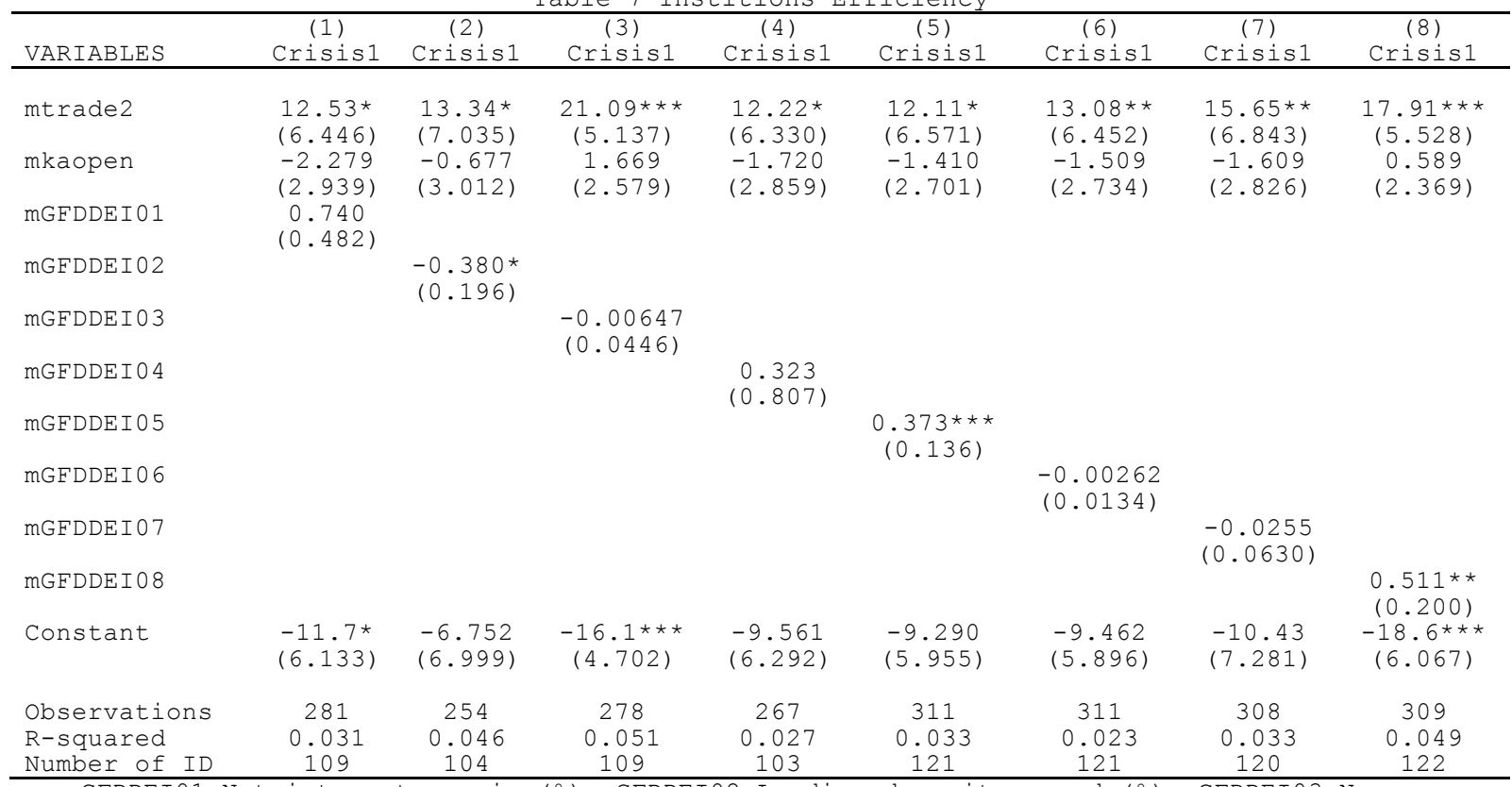

GFDDEI01 Net interest margin (\%); GFDDEI02 Lending-deposit spread (\%); GFDDEI03 Non-

interest income to total income (\%); GFDDEI04 Overhead costs to total assets ( $\%)$;

GFDDEI05 Return on assets (\%); GFDDEI06 Return on equity (\%); GFDDEI07 Cost to income

ratio (\%); GFDDEI08 Credit to government and state-owned enterprises to GDP (\%);

Standard errors in parentheses; $* * * \mathrm{p}<0.01, * * \mathrm{p}<0.05, * \mathrm{p}<0.1$

\begin{tabular}{|c|c|c|c|c|c|c|}
\hline VARIABLES & $\begin{array}{c}1) \\
\text { Crisis1 } \\
\end{array}$ & $\begin{array}{c}(2) \\
\text { Crisis1 } \\
\end{array}$ & $\begin{array}{c}\text { (3) } \\
\text { Crisis1 } \\
\end{array}$ & $\begin{array}{c}(4) \\
\text { Crisis1 } \\
\end{array}$ & $\begin{array}{c}(5) \\
\text { Crisis1 } \\
\end{array}$ & $\begin{array}{c}(6) \\
\text { Crisis1 } \\
\end{array}$ \\
\hline $\begin{array}{l}\text { mtrade } 2 \\
\text { mkaopen }\end{array}$ & $\begin{array}{c}25.02 * \star \star \\
(5.568) \\
3.265 \\
(3.488)\end{array}$ & $\begin{array}{c}22.29 * \star \star \\
(5.580) \\
3.480 \\
(3.415)\end{array}$ & $\begin{array}{l}11.15 \\
(8.768) \\
-0.176 \\
(3.632)\end{array}$ & $\begin{array}{c}22.94 * \star \star \\
(6.564) \\
4.327 \\
(3.746)\end{array}$ & $\begin{array}{c}23.34 * \star \star \\
(8.636) \\
3.397 \\
(3.925)\end{array}$ & $\begin{array}{c}33.39 * * * \\
(10.48) \\
4.382 \\
(3.644)\end{array}$ \\
\hline mGFDDDM0 1 & $\begin{array}{c}0.00353 \\
(0.0418)\end{array}$ & & & & & \\
\hline mGFDDDM0 2 & & $\begin{array}{c}-0.00593 \\
(0.0146)\end{array}$ & & & & \\
\hline mGFDDDM0 7 & & & $\begin{array}{c}-0.284 * * \\
(0.116)\end{array}$ & & & \\
\hline mGFDDDM0 8 & & & & $\begin{array}{c}-0.198 * * \\
(0.0981)\end{array}$ & & \\
\hline mGFDDDM0 9 & & & & & $\begin{array}{c}0.509 \\
(0.364)\end{array}$ & \\
\hline mGFDDDM1 0 & & & & & & $\begin{array}{c}-0.340 * * \\
(0.131)\end{array}$ \\
\hline Constant & $\begin{array}{c}-21.75 * \star \star \\
(5.382)\end{array}$ & $\begin{array}{c}-18.82 \star \star \star \\
(5.304)\end{array}$ & $\begin{array}{l}-4.126 \\
(8.547)\end{array}$ & $\begin{array}{c}-17.12 \star \star \star \\
(5.709)\end{array}$ & $\begin{array}{c}-20.95 * \star \\
(8.205)\end{array}$ & $\begin{array}{c}-24.28 * \star \star \\
(8.979)\end{array}$ \\
\hline Observations & 166 & 163 & 144 & 142 & 148 & 149 \\
\hline R-squared & 0.066 & 0.058 & 0.035 & 0.067 & 0.050 & 0.079 \\
\hline Number of ID & 62 & 60 & 59 & 53 & 59 & 58 \\
\hline
\end{tabular}

GFDDDM01Stock market capitalization to GDP (\%); GFDDDM02 Stock market total value traded to GDP ( $\left.\frac{\circ}{\circ}\right)$; GFDDDM07 International debt issues to GDP (\%); GFDDDM08 Gross portfolio equity liabilities to GDP (\%); GFDDDM09 Gross portfolio equity assets to GDP (\%); GFDDDM10 Gross portfolio debt liabilities to GDP (\%) ; Standard errors in parentheses; $* \star \star \mathrm{p}<0.01, * \star \mathrm{p}<0.05, * \mathrm{p}<0.1$

\begin{tabular}{lccccc}
\multicolumn{7}{c}{ Table } & 9-Institution Depth \\
\hline VARIABLES & $\begin{array}{c}(1) \\
\text { low gov }\end{array}$ & $\begin{array}{c}(2) \\
\text { low gov }\end{array}$ & $\begin{array}{c}(3) \\
\text { high } \\
\text { gov }\end{array}$ & $\begin{array}{c}(4) \\
\text { high } \\
\text { gov }\end{array}$ & $\begin{array}{c}\text { (5) } \\
\text { low gov }\end{array}$ \\
\hline mtrade2 & -4.246 & -0.140 & $17.27 * *$ & 13.25 & -4.312 \\
mkaopen & $(13.14)$ & $(13.49)$ & $(8.323)$ & $(8.502)$ & $(13.09)$ \\
mGFDDDI01 & -5.592 & 1.813 & $-5.6 * *$ & $-5.4 * *$ & -5.680 \\
& $(7.639)$ & $(6.634)$ & $(2.473)$ & $(2.516)$ & $(7.610)$ \\
& $(0.604)$ & & & &
\end{tabular}




\begin{tabular}{|c|c|c|c|c|c|}
\hline mGFDDDI 02 & & $\begin{array}{l}0.901^{\star} \\
(0.478)\end{array}$ & & & \\
\hline mGFDDDI 04 & & & $\begin{array}{c}0.181 \\
(0.176)\end{array}$ & & \\
\hline mGFDDDI 06 & & & & $\begin{array}{l}-0.089 \\
(0.266)\end{array}$ & \\
\hline mGFDDDI 12 & & & & & $\begin{array}{l}1.393 * * \\
(0.603)\end{array}$ \\
\hline Constant & $\begin{array}{l}-14.95 \\
(14.00)\end{array}$ & $\begin{array}{l}-13.84 \\
(14.68)\end{array}$ & $\begin{array}{c}-29.06^{*} \\
(17.20)\end{array}$ & $\begin{array}{l}-8.829 \\
(7.935)\end{array}$ & $\begin{array}{c}-15.85 \\
(14.11)\end{array}$ \\
\hline $\begin{array}{l}\text { Observations } \\
\text { R-squared } \\
\text { Number of ID }\end{array}$ & $\begin{array}{l}58 \\
0.197 \\
34\end{array}$ & $\begin{array}{l}58 \\
0.153 \\
33\end{array}$ & $\begin{array}{l}215 \\
0.065 \\
98\end{array}$ & $\begin{array}{l}210 \\
0.049 \\
97\end{array}$ & $\begin{array}{c}58 \\
0.203 \\
34\end{array}$ \\
\hline
\end{tabular}

mGFDDDI01Bank private credit to GDP; mGFDDDI02 Deposit bank money to GDP; mGFDDDI04

Deposit money bank assets to deposit money bank assets and central bank assets;

mGFDDDI06 Central bank assets to GDP;mGFDDDI12 Private credit by deposit money banks and other financial institutions to GDP (\%). Standard errors in parentheses*** p<0.01, $\star * \mathrm{p}<0.05, * \mathrm{p}<0.1$

Table 10-Institions Stability \&Efficiency

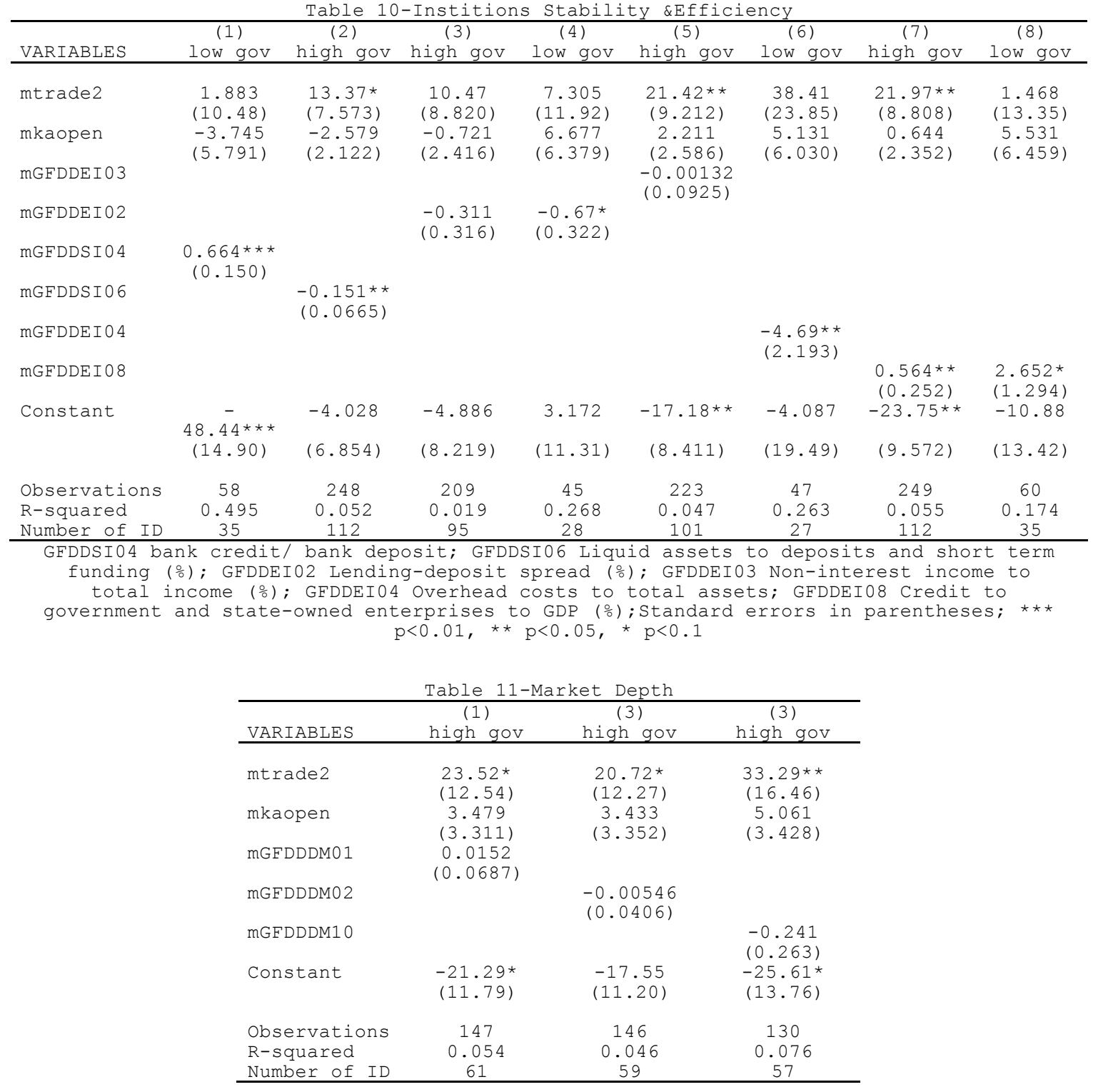

GFDDDM01Stock market capitalization to GDP (\%); GFDDDM02 Stock market total value traded to GDP GFDDDM10 Gross portfolio debt liabilities to GDP (\%) ; Standard errors

in parentheses standard errors in parentheses; $\star \star \star p<0.01, * \star p<0.05, * p<0.1$ 
Table A1 - Variables' Definitions and Sources

\begin{tabular}{|c|c|c|}
\hline $\begin{array}{l}\text { VARIABLES } \\
\text { NAMES }\end{array}$ & $\begin{array}{l}\text { Variables } \\
\text { Definition }\end{array}$ & Source \\
\hline Crisis & $\begin{array}{l}\text { Difference between actual and predicted GDP per capita } \\
\text { growth rate in } 2008,2009 \text { and } 2010 \text {. As for } 2008 \text { : GDP per } \\
\text { capita growth rate for } 2008 \text { as reported in WEO } 2015 \text { - } \\
\text { GDP per capita growth rate for } 2008 \text { as reported in WEO } \\
2008 \text {. As for } 2009 \text { ( } 2010) \text { : GDP per capita growth rate } \\
\text { for } 2009 \text { ( } 2010) \text { as reported in WEO } 2015 \text { - GDP per } \\
\text { capita growth rate for } 2009 \text { as reported in WEO } 2008\end{array}$ & $\begin{array}{l}\text { International } \\
\text { Monetary } \\
\text { Fund, World } \\
\text { Economic } \\
\text { Outlook, } \\
\text { April } 2008 \\
\text { and April } \\
2015 ; \text { Own } \\
\text { Calculations }\end{array}$ \\
\hline \multicolumn{3}{|c|}{ Trade \& Capital openness } \\
\hline mtrade & trade openness (import and export to GDP) & $\begin{array}{l}\text { World Bank, } \\
\text { World } \\
\text { Development } \\
\text { Indicators }\end{array}$ \\
\hline mkaopen & $\begin{array}{l}\text { Chinn and Ito Index of capital openness. This index is } \\
\text { the first standardized principal component of the four } \\
\text { binary variables that are measured in the IMF AREAER. } \\
\text { It is bounded between } 0 \text { and } 1 \text {. The more open the } \\
\text { country, the higher the index. }\end{array}$ & $\begin{array}{l}\text { Chinn and Ito } \\
\text { Dataset, } \\
\text { latest issue } \\
\text { available, } \\
05 / 01 / 2015 \\
\text { Portland } \\
\text { State } \\
\text { University }\end{array}$ \\
\hline \multicolumn{3}{|c|}{ Financial Institutions Depth } \\
\hline mGFDDDI01 & $\begin{array}{l}\text { Bank private credit to GDP. The financial resources } \\
\text { provided to the private sector by domestic money banks } \\
\text { as a share of GDP. }\end{array}$ & $\begin{array}{l}\text { Global } \\
\text { Financial } \\
\text { Development } \\
\text { Database } \\
\text { (GFDD), } \\
\text { World Bank. } \\
\text { (Čihák et al, } \\
2012 \text { ) }\end{array}$ \\
\hline mGFDDDI02 & $\begin{array}{l}\text { Deposit bank money to GDP. Assets include claims on } \\
\text { domestic real nonfinancial sector which includes } \\
\text { central, state and local governments, nonfinancial } \\
\text { public enterprises and private sector. Deposit money } \\
\text { banks comprise commercial banks and other financial } \\
\text { institutions that accept transferable deposits, such as } \\
\text { demand deposits. }\end{array}$ & GFDD \\
\hline mGFDDDI 04 & $\begin{array}{l}\text { Deposit money bank assets to deposit money bank assets } \\
\text { and central bank assets. Assets include claims on the } \\
\text { domestic real nonfinancial sector, which includes } \\
\text { central, state and local governments, nonfinancial } \\
\text { public enterprises and private sector. Deposit money } \\
\text { banks comprise commercial banks and other financial } \\
\text { institutions that accept transferable deposits, such as } \\
\text { demand deposits. }\end{array}$ & GFDD \\
\hline mGFDDDI 05 & $\begin{array}{l}\text { Liquid liabilities to GDP. Ratio of liquid liabilities } \\
\text { to GDP. Liquid liabilities are also known as 'broad } \\
\text { money', or M3. They are the sum of currency and } \\
\text { deposits in the central bank (M0), plus transferable } \\
\text { deposits and electronic currency (M1), plus time and } \\
\text { savings deposits, foreign currency transferable } \\
\text { deposits, certificates of deposit, and securities } \\
\text { repurchase agreements (M2), plus travelers checks, } \\
\text { foreign currency time deposits, commercial paper, and } \\
\text { shares of mutual funds or market funds held by } \\
\text { residents. }\end{array}$ & GFDD \\
\hline mGFDDDI0 6 & $\begin{array}{l}\text { Central bank assets to GDP. Central bank assets are } \\
\text { claims on the domestic real nonfinancial sector by the } \\
\text { Central Bank. }\end{array}$ & GFDD \\
\hline mGFDDDI0 8 & $\begin{array}{l}\text { Financial system deposits to GDP. Demand, time and } \\
\text { saving deposits in deposit money banks and other } \\
\text { financial institutions as a share of GDP. }\end{array}$ & $\begin{array}{l}\text { GFDD } \\
\text { GFDD }\end{array}$ \\
\hline mGFDDDI 12 & $\begin{array}{l}\text { Private credit by deposit money banks and other } \\
\text { financial institutions to GDP. Private credit by } \\
\text { deposit money banks and other financial institutions to } \\
\text { GDP. }\end{array}$ & $\begin{array}{l}\text { GFDD } \\
\text { GFDD }\end{array}$ \\
\hline \multicolumn{3}{|c|}{ Financial Market Depth } \\
\hline mGFDDDM0 1 & $\begin{array}{l}\text { Stock market capitalization to GDP. Total value of all } \\
\text { shares listed on a stock market as a percentage of GDP. }\end{array}$ & GFDD \\
\hline
\end{tabular}


mGFDDDM0 2

mGFDDDM0 8

mGFDDDM10

GFDDAI0 2

mGFDDDM0 9

Stock market total value traded to GDP (\%). Total value of all shares traded in a stock market exchange as a percentage of GDP.

International debt issues to GDP. Total value of outstanding international debt issues both public and private, as a share of GDP.

Gross portfolio equity liabilities to GDP. Ratio of gross portfolio equity liabilities to GDP. Equity liabilities include shares, stocks, participations, and similar documents (such as American depository receipts) that usually denote ownership of equity.

Gross portfolio equity assets to GDP. Ratio of gross portfolio equity assets to GDP. Equity assets include shares, stocks, participations, and similar documents (such as American depository receipts) that usually denote ownership of equity.

Gross portfolio debt liabilities to GDP (\%). Ratio of gross portfolio debt liabilities to GDP. Debt

liabilities cover (1) bonds, debentures, notes, etc., and (2) money market or negotiable debt instruments.

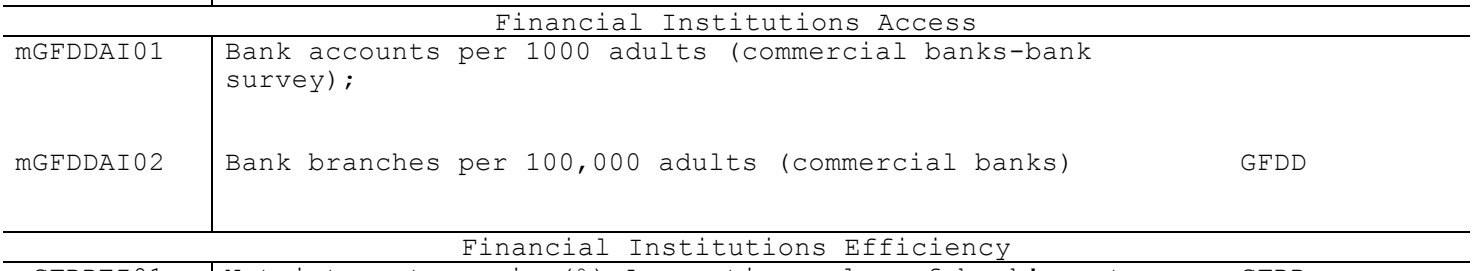

mGFDDEI01 $\quad$ Net interest margin (\%). Accounting value of bank's net interest revenue as a share of its average interestbearing (total earning) assets.

mGFDDEI02 Lending-deposit spread (\%). Difference between lending rate and deposit rate. Lending rate is the rate charged by banks on loans to the private sector, and deposit interest rate is the rate offered by commercial banks on three-month deposits.

mGFDDEI03 Non-interest income to total income (\%). Bank's income that has been generated by non-interest related activities as a percentage of total income (netinterest income plus non-interest income). Non-interest related income includes net gains on trading and derivatives, net gains on other securities, net fees and commissions and other operating income.

mGFDDEIO4 Overhead costs to total assets (\%). Operating expenses of a bank as a share of the value of all held assets. Total assets include total earning assets, cash and due from banks, foreclosed real estate, fixed assets, goodwill, other intangibles, current tax assets, deferred tax, discontinued operations and other assets.

MGFDDEI0 5

Return on assets ( $\left.\frac{\circ}{0}\right)$. Commercial banks' net income to yearly averaged total assets.

mGFDDEI06 Return on equity (응. Commercial banks' net income to yearly averaged equity. as a share of the sum of net-interest revenue and other operating income.

mGFDDEIO 8 Credit to government and state-owned enterprises. Ratio between credit by domestic money banks to the government and state-owned enterprises and GDP.

\begin{tabular}{l|l}
\multicolumn{2}{c}{ Financial Institutions stability } \\
\hline mGFDDSI01 & Bank z score. This captures the probability of default
\end{tabular}
of a country's banking system, calculated as a weighted average of the $z$-scores of a country's individual banks (the weights are based on the individual banks' total assets). the z-score compares a bank's buffers (capitalization and returns) with the volatility of those returns.

bank credit/ bank deposit. The financial resources provided to the private sector by domestic money banks as a share of total deposits. Domestic money banks comprise commercial banks and other financial 


\begin{tabular}{|c|c|c|}
\hline mGFDDSI0 6 & $\begin{array}{l}\text { institutions that accept transferable deposits, such as } \\
\text { demand deposits. Total deposits include demand, time } \\
\text { and saving deposits in deposit money banks. } \\
\text { Liquid assets to deposits and short term funding } \\
(\text { o }) \text {. The ratio of the value of liquid assets (easily } \\
\text { converted to cash) to short-term funding plus total } \\
\text { deposits. Liquid assets include cash and due from } \\
\text { banks, trading securities and at fair value through } \\
\text { income, loans and advances to banks, reverse repos and } \\
\text { cash collaterals. Deposits and short term funding } \\
\text { includes total customer deposits (current, savings and } \\
\text { term) and short term borrowing (money market } \\
\text { instruments, cDs and other deposits) }\end{array}$ & GFDD \\
\hline \multicolumn{3}{|c|}{ Political Instiutions } \\
\hline highpolstab & $\begin{array}{l}\text { Dummy which takes value one if Political stability } \\
\text { takes a value greater than the } 25^{\text {th }} \text { percentile. }\end{array}$ & $\begin{array}{l}\text { Worldwide } \\
\text { Governance } \\
\text { Indicators } \\
\text { (WGI) }\end{array}$ \\
\hline highvoice & $\begin{array}{l}\text { Dummy which takes value one if Voice and Accountability } \\
\text { take a value greater than the } 25^{\text {th }} \text { percentile. }\end{array}$ & WGI \\
\hline highgoveff & $\begin{array}{l}\text { Dummy which takes value one if Government Effectiveness } \\
\text { takes a value greater than the } 25^{\text {th }} \text { percentile. }\end{array}$ & WGI \\
\hline highregqual & $\begin{array}{l}\text { Dummy which takes value one if Regulatory Quality takes } \\
\text { a value greater than the } 25^{\text {th }} \text { percentile. }\end{array}$ & WGI \\
\hline Highrule & $\begin{array}{l}\text { Dummy which takes value one if Rule of Law takes a } \\
\text { value greater than the } 25^{\text {th }} \text { percentile. }\end{array}$ & WGI \\
\hline highcorrup & $\begin{array}{l}\text { Dummy which takes value one if control of Corruption } \\
\text { takes a value greater than the } 25^{\text {th }} \text { percentile. }\end{array}$ & WGI \\
\hline
\end{tabular}

${ }^{*}$ Faculty of Business and Law, London Metropolitan University (UK).

${ }^{* *}$ School of Slavonic and East European Studies, University College London (UK).

${ }^{* * *}$ Department of Economics, University of Perugia (Italy).

${ }^{1}$ Due to increased globalization, many emerging economies are exposed to external economic shocks (e.g., Kutan, 2015). However, what exactly determines the vulnerabilities to global turmoil remains a contentious matter.

${ }^{2}$ It was especially with the collapse of Lehman Brothers (September 2008) that a remarkable global diffusion of the US crisis became much more evident.

${ }^{3}$ The predicted values of national GDP growth rates published in April 2008 by IMF are, obviously, the latest forecasts available for that time and refer to estimations made in the year 2007 or 2006.

4 The Cronbach Coefficient Alpha assesses how a set of indicators measures a uni-dimensional concept (OECD, 2008 ). This technique is useful for clustering similar variables. It therefore seems particularly appropriate for the chosen Kaufmann indicators, which are highly correlated.

${ }^{5}$ We also carried out the same exercise with a different threshold: that is, we used the mean of the institutional indicators to create the two sub-samples of interest. These results are not reported here but are available upon request.

${ }^{6}$ It is worth mentioning that, in order to verify whether the differences observed in the two groups were statistically significant, we carried out a further check. That is, we ran a regression between the variable of interest (i.e. any of the explanatory variables of Equation 1) and the dummy classifying the two groups of countries. If both the variable of interest and the interaction term were statistically significant, it could be concluded that the effect of the selected explanatory variable was different across the two groups (i.e. very low vs. good quality institutions); and hence that internal institutions played a major role in determining the severity of the crisis in terms of output loss

${ }^{7}$ To be noted is that, following the suggestion of an anonymous referee, we have replicated our exercise in three distinct cross-sections, one for each of the years considered (i.e. 2008-2010). The results of our main exercise are qualitatively unaltered. To save space, we do not report them here, but they are available upon request. We thank a referee for suggesting this important robustness check.

${ }^{8}$ To be noted is that, in order to assess the relative importance of financial institutions and financial markets, we have split our sample into bank-based and market-based economies. This has been done following the recent work of Gambacorta et al.(2014). In line with Levine (2002), Beck and Levine (2002) and Chakraborty and Rayb (2006) we do not find evidence that one system 
outperforms the other in terms of making countries more resilient to global financial turmoil. To save space we have not reported these results here, but they are available upon request. We are grateful to an anonymous referee for providing this suggestion.

9 As for the magnitude of the impact of trade openness, although our results are not comparable with others existing in the literature (mainly due to different specifications or periods), it should be highlighted that we find a quite high value of the coefficient (as detailed above).

10 Differently, Maa (2015) reports that increased financial openness is associated with sharper volatility in the presence of foreign shocks. Consequently, it can aggravate the impact of a crisis.

${ }^{11}$ Although the effect of this variable is not statistically significant, its positive sign and, especially, the (jointly) significant role of capital openness suggest future research on the potential and effective actions of the central banks in emerging economies in crisis times.

12 In particular, they show that, in the case of developing countries, distorted incentives within the financial sector can increase the likelihood of crises, making such countries more vulnerable.

${ }^{13}$ Although the 2008 financial crisis was the worst since 1929, it should be noted that reforms of "regulatory system and governance" have been - until now - very scarce at both international and national levels. Moreover, on a Keynesian view, it is important to mention that, on the occurrence of a financial crisis, the timing and size of the counter-cyclical monetary and fiscal policies are fundamental for reducing the magnitude and duration of a recession: for example, the very different cumulative real impact of the global financial crises in the US and in Europe (especially Eurozone) can be - at least partly - explained by the very different features and timing of the monetary and fiscal policies (e.g. Marelli and Signorelli, 2015).

${ }^{14}$ For a study adopting a long run approach not focused on crisis time, see Bonnala and Yayab (2015) who investigate the relationship among political institutions, trade openness, and economic growth using a panel of over 200 countries and eight non-overlapping five-year average observations for the period $1975-2010$. 